\title{
Una olvidada imitación del Quijote en la España de finales del XVIII: El tío Gil Maтuco (1789), de Francisco Vidal y Cabasés. Contextualización y análisis
}

\author{
Javier Muñoz de Morales Galiana*
}

\begin{abstract}
Resumen
Cervantes fue uno de los principales referentes literarios para los novelistas de la España del XVIII. A partir de la publicación de Don Quijote de la Manchuela, aparecieron numerosas imitaciones del Quijote que tenían en común su carácter satírico, basado en la utilización de un personaje presuntamente «quijotesco» para ridiculizar un determinado tipo social. En 1789 se publicó, siguiendo esta tendencia, El tío Gil Mamuco, de Francisco Vidal y Cabasés, una novela actualmente olvidada y apenas referida por la crítica, ni siquiera por quienes se han ocupado del ámbito de la novela española dieciochesca. Dicho título, no obstante, destaca frente a otras imitaciones del Quijote porque pretende ser, aparte de una burla hacia las personas supersticiosas, un artefacto esencialmente lúdico, para lo cual juegan un papel fundamental la utilización de lo extraño y los lugares de indeterminación al sugerir la presencia de sustancias psicoactivas utilizadas por el protagonista.
\end{abstract}

Palabras clave: Ilustración; superstición; locura; docere et delectare; Quijote.

Title: A Forgotten Imitation of the Quixote in the Spain of Endings of the EighteenthCentury: El tío Gil Mamuco (1789), by Francisco Vidal y Cabasés. Contextualization and Analysis

\footnotetext{
Abstract

Cervantes was one of the main role models for the novelists of the eighteenth-century Spain. From the publication of Don Quijote de la Manchuela, numerous imitations of Don

* Universidad de Cádiz. javier.munozdemorales@uca.es / ORCID iD: https://orcid.org/00000002-4988-9280
} 
Quixote appeared had in common their satirical character, based on the use of a presumably «quixotic» character to satirize a certain social type. Following this trend, El Tío Gil Матисо by Francisco Vidal y Cabasés was published in 1789, a novel currently forgotten and hardly referred to by critics, not even by those who have dealt with the sphere of the eighteenth-century Spanish novel. This title, however, stands out compared to other imitations of Don Quixote because it tries to be not only a mockery of superstitious people, but also an essentially playful device, for which the use of the strange and the places of indeterminacy play a fundamental role when suggesting the presence of psychoactive substances used by the protagonist.

Keywords: Enlightenment; Superstition; Madness; Docere et Delectare; Quixote.

\section{Cómo citar este artículo / Citation}

Muñoz de Morales Galiana, Javier. 2021. «Una olvidada imitación del Quijote en la España de finales del XVIII: El tío Gil Mamuco (1789), de Francisco Vidal y Cabasés. Contextualización y análisis». Anales Cervantinos 53: 173-200. https://doi.org/10.3989/anacervantinos.2021.007

\section{UNA ÉPOCA DE IMITACIONES QUIJOTESCAS}

Para hablar de El tío Gil Maтисо, obra casi desconocida y carente de edición moderna, es necesario comenzar remontándonos a la importancia de las imitaciones quijotescas habidas en España a finales del XVIII, tendencia con amplia trayectoria (Álvarez Barrientos 1991, 171-188) que se inició en 1767 con la novela Don Quijote de la Manchuela, de Donato Arenzana ${ }^{1}$, y continuó a lo largo del XVIII y parte del XIX².

De la novela de Arenzana es significativa la dedicatoria con la que se abre la obra, «A la necedad». Con ella nos está insinuando cuál va a ser su intención, esto es, satirizar a las personas que él considera necias habidas en la sociedad. Actitud, en realidad, mucho más cercana a la de José Francisco de Isla en el Fray Gerundio que a la de Cervantes. Decir que don Quijote es simplemente «necio» supone, en términos de Ingarden, una «maliciosa falsificación» de la obra literaria, consecuencia de que ni ha tenido lugar una «aprehensión adecuada» ni ha sido «captada correctamente» (1989, 41); pero precisamente esa «falsificación» fue la que imperó en casi todos los escritores dieciochescos que llevaron a cabo una imitación cervantina. Dado que en la Francia del XVIII tampoco se habían logrado captar

1. Sátira contra la mala educación de los literatos, en la línea del Fray Gerundio. Si el don Quijote de Cervantes se comportó de manera estrafalaria en el ejercicio de las armas, don Quijote «de la Manchuela» pretende ser su equivalente en el terreno de las letras. Para un análisis de esta novela, véase Chicharro (2005).

2. Para un catálogo de las imitaciones del Quijote habidas en España durante esta época, véase López Navia $(2013,23-25)$. 
todos los matices del Quijote ${ }^{3}$, las influencias de este país, referente en la Europa de la Ilustración, pudieron haber condicionado esta lectura, lo que se hace muy evidente en, por ejemplo, la Vida de Juan Mayorazgo (1779) ${ }^{4}$. $\mathrm{Su}$ autor utiliza el término «quijotesco», pero entiende por «quijotesco» un hombre «finchado», «simple» y «mentecato» (Ponce de León 2012, 33-34). La novela, de hecho, narra la vida de una persona que, por tener el privilegio de ser el mayorazgo de su familia, desdeña llevar a cabo nada productivo, y opta por actividades que no le suponen ningún tipo de provecho ni a él ni a nadie de su entorno.

Casi todas las imitaciones del Quijote posteriores siguieron la misma línea. En 1787 y 1788 se publica en dos partes el Quijote escolástico, una sátira contra las personas que continúan sirviéndose de la filosofía escolástica en el siglo XVIII ${ }^{5}$. Entre 1792 y 1800, en tres tomos, aparece el Quijote de la Cantabria, protagonizado por un sujeto estrafalario que pretende reivindicar la importancia histórica de la zona de Cantabria. En 1814, de igual manera, se publicó el primer tomo de Don Papis de Bobadilla 6 , y el único de El liberal en Cádiz, obras ambas protagonizadas por personajes grotescos y «quijotescos» a causa de su heterodoxia -solo religiosa en el primer caso, política también en el segundo-- En 1818, José Joaquín Fernández de Lizardi publica La quijotita y su prima, en la que la protagonista recibe el apodo de «quijotita» por no querer resignarse a las limitaciones sociales de la mujer, lo cual es visto, de nuevo, como algo necio. Muchas otras obras similares aparecieron a lo largo del XIX.

De esta tendencia a intentar imitar el Quijote en esos términos, deducimos una lectura de la obra que no terminaba de contemplarla en toda su complejidad. Recordemos que los «criterios de valor» de las obras literarias, como bien señala Vodička, «no son estables, de manera que el valor de una obra no es desde el punto de vista de las fuentes históricas una magnitud inmutable» $(1989,55)$. En este sentido, los escritores del XVIII español, a diferencia de lo que ocurriría en la posteridad, se limitaban a ver en don Quijote alguien «ridículo», y en sus imitaciones queda reproducida esa ridiculez; sus personajes, por ello, están caracterizados fundamentalmente por la estulticia ${ }^{7}$.

3. Remitámonos, si no, a las conclusiones de Bardon en su trabajo sobre el Quijote en la Francia del XVIII: «La mentalidad clásica que los caracterizaba [a los franceses] no les impidió disfrutar de tal libro, pero sí analizar e interpretar el divertido contraste entre el enjuto e idealista caballero y su pragmático y orondo escudero; no estaban en condiciones de captar la singular originalidad de la novela, que les pasó desapercibida» $(2010,971)$.

4. El interés de esta novela ha sido reivindicado recientemente, en una edición aparecida en 2012 a cargo de Maurizio Fabbri. Se trata de una de las más logradas imitaciones del Quijote habidas en el XVIII español; en este caso, el protagonista es, en palabras de su autor, un «Don Quijote riojano» (Ponce de León 2012, 32).

5. Para un análisis de esta novela, véase Sánchez Sánchez (2001).

6. Si bien esta obra suele aparecer fechada en 1829, sabemos que empezó a publicarse en 1814 gracias al trabajo de Álvarez de Miranda (1999).

7. Para una visión más completa de los diferentes matices que tuvo el cervantismo en la España de aquellos años, véase Cuevas Cervera (2015). 
Juan Pablo Forner, autor de las Exequias de la lengua castellana, sintetizó esta mentalidad con respecto al Quijote en las siguientes palabras: «Cervantes [...] creó el estilo jocoso y dio inimitables ejemplos de la narración fácil y amena, del diálogo urbano y elegante, del arduo modo de expresar con las frases la ridiculez de los hombres» (Forner 2003, 240, la cursiva es nuestra). Sebold ya señaló, con bastante acierto, la incomprensión del Quijote por parte de alguien que sostenga un argumento así (1970, 117); el error interpretativo de Forner es, en esencia, el mismo que cometieron muchos de sus contemporáneos al configurar sus «quijotes» con base solo en la faceta más grotesca del protagonista cervantino.

Aunque haya ridiculez, no hay locura en ninguna de estas obras: es la «necedad», como bien señalaba Arenzana, lo que origina cada uno de los extravíos de todos estos «quijotes». Chicharro, al analizar este Quijote de la Manchuela, define el concepto de «necedad» utilizado en esa novela como «la incultura extendida por todas partes, la ignorancia», así como la ineptitud de la «España rural y atrasada que representa, frente a la fecunda modernidad de un porvenir que ya se entrevé, mucho más moderno y mucho más abierto en las mentes lúcidas del siglo, en los ilustrados, entre las cuales se cuenta Arenzana» (2005, 12-13). Chicharro ya advierte este reduccionismo al situar el Quijote de la Manchuela entre «las múltiples obras españolas de imitación cervantina que utilizaron el texto como medio para censurar los vicios, los defectos sociales, las malas costumbres del momento» $(2005,16)$.

Pero no todos los intelectuales de la época fueron incapaces de ir más allá de esa «falsificación» del Quijote, sino que algunos pudieron llevar a cabo lo que Wolfgang Iser llama «actualización» del texto literario, esto es, cuando este «es entendido de manera algo distinta por diferentes lectores» (1989, 134); en concreto, destaca la visión crítica que tuvo Gaspar Melchor de Jovellanos con respecto a tales imitaciones cervantinas. Dicho autor reparó en la locura, que no la «necedad», como una de las características más singulares de don Quijote ${ }^{8}$. Consciente de esta diferencia, envió una carta en 1793 al autor del Quijote de la Cantabria, en la que le reprochaba lo siguiente:

\footnotetext{
Vio usted que a Don Quijote se le había vuelto el juicio a fuerza de leer libros de caballerías, y quiso, por lo mismo, ensandecer a Don Pelayo a fuerza de leer historias, particularmente de su patria, y reconocer papeles. Paso de gracia que no es lo mismo uno que otro para esto de volver el juicio; paso, y también de gracia, que usted no se atreve a volver loco a Don Pelayo, ni sabría qué hacer de él si se hubiese atrevido (Jovellanos 1985, 597).
}

Muy similar a la interpretación de Jovellanos fue la de Vicente de los Ríos (1780), quien supo advertir la importancia de la locura en la obra de Cervantes, hasta el punto de considerarla el tema principal de la obra y uno de los

8. Una visión muy similar puede encontrarse en el Análisis del Quijote de Vicente de los Ríos (1780), que constituye uno de los principales hitos del cervantismo en aquellos años. 
principales motivos del interés de esta, por la «extravagancia y novedad» que implicaba (1780, LXIX). La locura, para este autor, hacía del Quijote una lectura más agradable que la épica clásica, porque los textos de Homero tendrían una desventaja frente al de Cervantes, y es que el «anticipado conocimiento» de que los héroes van a triunfar «quita parte de la novedad a los sucesos, y disminuye la curiosidad previniéndola», a diferencia de lo que ocurre con la locura, que aporta un importante matiz de imprevisibilidad a la novela $(1780, \mathrm{LV})$.

Por tanto, no todos los intelectuales españoles de finales del XVIII seguían la lectura falsificada que quedó enunciada en Forner; además de los ya conocidos casos de Jovellanos y Ríos, «tampoco su utilización como base para las imitaciones es igualitaria, ni siempre mantenida» (Cuevas Cervera 2015, 89), ejemplo de lo cual lo sería la novela que aquí nos ocupa, El tío Gil Mamuco, obra olvidada y apenas estudiada ${ }^{9}$, pero que, como veremos, destaca frente a otras imitaciones cervantinas por configurar su protagonista no solo con base en lo grotesco, sino, concretamente, en la locura.

Partimos, no obstante, de una diferencia fundamental entre los textos de Ríos y Jovellanos frente al que aquí vamos a analizar. Estos dos, en todo momento, le conceden importancia a la locura al analizar la obra de Cervantes -lo que, en realidad, tampoco implica una lectura del Quijote menos «falsa»-10; el autor de El tío Gil Mamuco, en cambio, se sirve de este mismo concepto como temática central de su obra, y resulta muy llamativo que, en este punto, se distancie de todos los otros imitadores cervantinos de la Espa-

9. La novela, hasta el momento, no ha sido analizada por extenso, si bien debemos tener en cuenta las ocasiones en las que ha sido comentada brevemente antes de dar comienzo a nuestro análisis. Cotarelo de hecho, se refiere a ella como una obra de escaso mérito, y nos ofrece algunas pinceladas sobre el personaje principal, el tío Gil, «un caballero andante de la industria y los inventos, pero no de la industria seria y provechosa, sino de una multitud de pequeños oficios e invenciones que en aquella época abundaban en nuestra patria y cuya manía pretende el autor ridiculizar» (1900, 16-17). Rodríguez Gutiérrez, por otro lado, se refiere a la novela como una narración «en la que se cuentan las andanzas de Gil Mamuco y su criado Blas Peguín proponiendo a todo el mundo los más peregrinos modos de vivir sin trabajar»; añade, además, que la obra está compuesta por distintas narraciones pequeñas que podrían considerarse cuentos independientes, los cuales no tienen en común más que el personaje principal y la intención satírica $(2004,47)$. Finalmente, García Gutiérrez afirma que el protagonista de la obra es «otro Quijote obsesionado esta vez con la alquimia, el esoterismo y libros sobre la búsqueda de la piedra filosofal» $(2007,35 \mathrm{n})$. No nos consta ningún otro autor que hasta ahora se haya detenido a analizarla pormenorizadamente.

10. Tengamos en cuenta que el concepto de «locura» que en todo momento manejan no se corresponde, en realidad, con el utilizado por Cervantes, en cuya obra tal término adquiría connotaciones diferentes. Con relación a la «necedad», el modo en que hemos visto que autores como Anzarena usaban tal término no era muy diferente al que podemos apreciar en la época de Cervantes; así, Covarrubias define por «necio» al «ignorante que sabe poco» $(1611,1122)$. El término «locura», en cambio, adquiría otras connotaciones a comienzos del XVII muy distintas de las que pudiera tener en el XVIII; hay, incluso, quienes han querido ver influencias de Erasmo de Rotterdam en la noción de «locura» que se desarrolla en el Quijote: «Esta naturaleza de la locura de don Quijote está muy de acuerdo con el concepto que de sí misma tiene la locura de Erasmo. [...] ¿Y qué es la locura de don Quijote sino esa "dulce ilusión" que lo lleva a abandonar su vida rutinaria para hacer de la ficción su vida?» (Fajardo 1985, 614). 
ña del XVIII ${ }^{11}$. Este contraste también justificaría el interés adicional que esta novela puede suponer, y nos permitiría orientar nuestro análisis a esclarecer las motivaciones que tuviera y los resultados que pudo, con ello, conseguir.

\section{AUTORÍA DE LA OBRA}

No obstante, resulta difícil acercarnos a discernir la respuesta a estas preguntas sin saber claramente la identidad de este escritor. El desconocimiento de quién fue el autor de esta obra quizá sea uno de los principales motivos por los que haya pasado desapercibida y obviada frente a otras imitaciones quijotescas de la época ${ }^{12}$; y es que la novela se publicó de forma parcialmente anónima, con no más que unas iniciales: D. F. V. Y. C. P. Tales son las siglas que aparecen en la edición de la que nos hemos servido, impresa en 1789, en Madrid, oficina de Aznar ${ }^{13}$. Trabajos posteriores han tratado de dar cuenta de la identidad del autor; Urzainqui (1984, 415n) y Querol $(2010,272)$, por ejemplo, afirman que el autor de la novela es Francisco Vidal y Cabasés ${ }^{14}$; sin embargo, Álvarez Barrientos (1996, 260) y Hernández Morillas (2014, 503-504) sugieren que probablemente sea Pedro María de Olive.

Para respaldar tal hipótesis, Álvarez Barrientos señala que en algunas ocasiones la obra ha sido atribuida, aparte de a «D. F. V. Y. C. P.», a un tal «D. P. M. O.», siglas que, según supone, son de «Don Pedro María de Olive»; este mismo dato es el utilizado por Hernández Morillas. Urzainqui, en cambio, señala un hecho concreto que resulta muy esclarecedor: a Pedro Centeno, autor del Quijote escolástico, se le encargó la censura de El tío Gil Mamuco, a partir de lo cual se ha podido averiguar que el autor del libro que censurar fue Francisco Vidal y Cabasés. En cuanto a Querol, en el artículo suyo que hemos citado se nos muestra gran conocedor de los escritores y de la literatura de Tortosa, pueblo natal de Vidal y Cabasés, de cuya vida también ofre-

11. Aparte de los ya mencionados casos del Quijote de la Manchuela y del Quijote de la Cantabria, debemos advertir que el contraste es idéntico con respecto a, por ejemplo, la Vida de Juan Mayorazgo (1779), en la que la comparación de su protagonista con don Quijote «es totalmente despreciativa, casi sinónimo de fanfarrón, irresoluto, fatuo, y que nada tiene que ver con el idealismo utópico que anima al protagonista de la obra maestra de Cervantes» (Fabbri 2012, 9). Lo mismo ocurre con el protagonista del Quijote escolástico, personaje más bien desdibujado y apenas desarrollado, ya que para caracterizarlo «es suficiente con pronunciar su nombre», y, en consecuencia, «no necesita describirlo»; de hecho, «es menos un personaje de novela que un instrumento satírico», puesto que el solo hecho de comparar a los escolásticos con don Quijote ya implicaba la ridiculización de los primeros (Sánchez Sánchez 2001, 381).

12. En el importante trabajo de Álvarez Barrientos (1991), por ejemplo, no se hace mención a este título.

13. Todas las citas de la obra presentes en este apartado provienen de esa misma edición.

14. Querol, en realidad, utiliza la forma catalana del nombre: «Francesc Vidal i Cabacés». No obstante, utilizamos aquí la lección española, «Francisco Vidal y Cabasés», que es la que el propio autor utilizaba para firmar las obras que publicó sin el anonimato, como las Conversaciones instructivas en que se trata de fomentar la agricultura por medio del riego de las tierras (Vidal y Cabasés 1778). 
ce bastantes detalles. No nos consta nadie que haya refutado esto con datos más sólidos; es más, en la edición que estamos manejando, única que hemos encontrado, las siglas que aparecen no son «D. P. M. O.», sino «D. F. V. Y. C. P.», que coinciden con «Don Francisco Vidal Y Cabasés, Presbítero». Su título de presbítero, de hecho, también aparece justo después de su nombre en sus Conversaciones instructivas (Vidal y Cabasés 1778). Todo esto nos lleva a considerar que, mientras no aparezcan evidencias más sólidas que indiquen lo contrario, Francisco Vidal y Cabasés debe ser tenido por el autor de El tío Gil Mamuco.

Tal escritor era clérigo e ilustrado y, al igual que Jovellanos, escribió bastante sobre agricultura con planteamientos muy novedosos, lo cual refleja una formación intelectual sólida e inclinada al progreso (Querol 2010, 272); un perfil, en definitiva, bastante similar al de cualquier otro español del Siglo de las Luces.

\section{CARACTERIZACIÓN DEL PROTAGONISTA}

El protagonista de esta novela es el mismo que le da título, el tío Gil Mamuco, un curandero que regenta una tienda de artículos esotéricos, y que vive obsesionado con cualquier tipo de asunto relativo a lo místico y sobrenatural. Su «quijotesca» locura raya en que se tiene a sí mismo por un poderoso hechicero, dotado de una magia devastadora y de una sabiduría inigualable. Un día, recibe la noticia de que un poderoso señor pretende ofrecer increíbles premios a aquellos que logren servirse de su sabiduría para formar a un mayor número de hombres de provecho. Creyéndose capaz de lograr ese premio, nuestro héroe comienza un extenso viaje en compañía de su criado, Blas Peguín, con el objeto de instruir al mayor número de personas posibles en sus supuestos conocimientos sobre magia y otras cuestiones sobrenaturales.

A partir de ahí, asistimos a una acumulación de sucesos en los que se demuestra paulatinamente que el tío Gil no posee ni una sola pizca de ese poder mágico del que tanto se jacta, y que no es, para nada, alguien sabio, sino una persona mentalmente desequilibrada e incapaz de admitir el verdadero funcionamiento del mundo real. A todos estos rasgos se le añade un carácter egoísta y narcisista hasta rayar en lo antisocial, lo cual lo lleva no solo a chocar contra la realidad en cada ocasión, sino también a provocar todo tipo de alborotos públicos cada vez que sus expectativas son defraudadas. El ímpetu violento del protagonista lo acaba arrastrando a crímenes en los que acaban dañados de todas las formas posibles muchos de sus semejantes, por lo que finalmente es encarcelado en compañía de su criado.

Por lo demás, se trata de un personaje plano, cuya locura se mantiene desde el primer capítulo hasta el último. En ello reside el carácter intercambiable de sus aventuras, puesto que, al no haber evolución, tanto daría que los sucesos narrados le acontezcan en el orden establecido o en cualquier otro. 
No obstante, a pesar de no modificarse el carácter del personaje a lo largo de los capítulos, sí que hay una descripción psicológica de este a través de toda la narración, porque el lector se va percatando de las distintas peculiaridades de su personalidad durante la obra. Suprimir muchos de los pasajes implicaría omitir detalles de su carácter, y ello haría de nuestro héroe, necesariamente, un personaje distinto. Las distintas narraciones, por ello, se complementan y se necesitan entre sí, y en su conjunto no solo forman un retrato detallado del tío Gil, sino también un discurso evidente sobre el papel inútil, innecesario y pernicioso de lo esotérico en la sociedad contemporánea al autor.

En el primer capítulo (1-23) se nos da información bastante significativa, pero incompleta. El narrador, la primera vez que habla de su personaje, nos lo describe como «un curandero algo falto de caletre, preciado de muy cuerdo, colérico y porfiado; pero tratable y amoroso, por cuyas buenas prendas muchos le alababan y querían» (1). Descripción algo vaga que no parece entrañar nada de particular; perfectamente podría responder a cualquier curandero de la época. En ese mismo capítulo, no obstante, podemos percibir algo de grotesco y de ridículo en él, fundamentalmente por sus similitudes con don Quijote, trocando la obsesión con los libros de caballería por otra tocante a la magia ${ }^{15}$ :

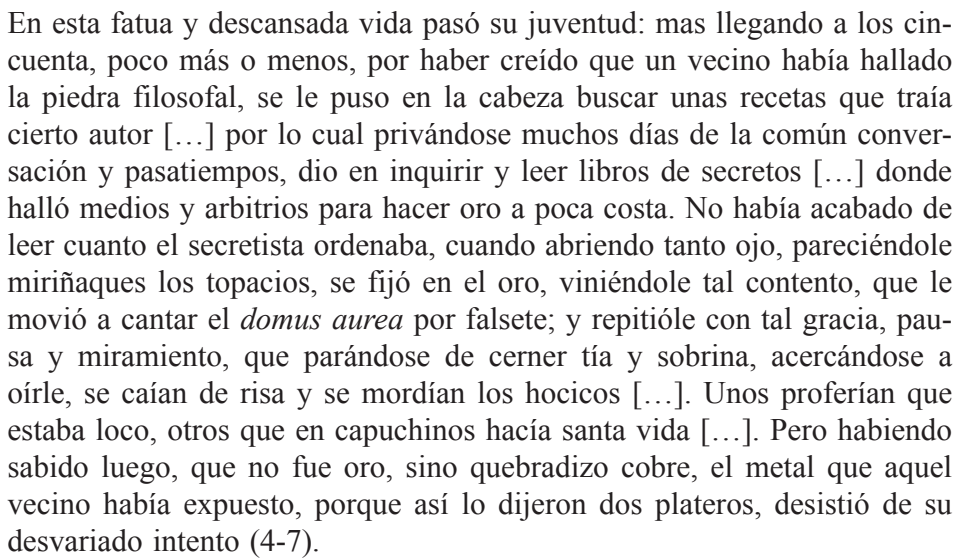

Por el momento, el tío Gil no es alguien necesariamente loco, sino crédulo, supersticioso, excéntrico y algo narcisista; esto último queda claro cuando afirma que va «a ganar un millón de pesos duros paseando» a fin de convertirse en «marqués o conde, y el más opulento de esta tierra» (12). En el segundo capítulo vemos hasta dónde pueden llegar su egocentrismo y su fantasía:

15. Adviértase que, a diferencia de lo que ocurría en la novela cervantina, Vidal y Cabasés está alertando al público de un peligro real. Don Quijote, al enloquecer presuntamente por leer novelas de caballería, no supone representación alguna de ninguna problemática social; caso distinto es el del tío Gil, cuya figura supondría, en este punto de la novela, una alusión directa a quienes seguían manteniendo supersticiones semejantes a finales del XVIII. 
En las chimeneas del reino, en las tertulias fuera de él, y en los paseos y boticas por temporadas largas se hablará de mí. Uno apostará que gano; otro contará nuevos progresos; este admirará mis invenciones, aquel deseará verme y escribirme, y no faltará quien diga «el diablo, es Gil Mamuco, bendita su alma de él» (30-31).

El carácter fantasioso del protagonista aquí se exagera en tanto que su relato sobre su supuesta vida futura se extiende hasta las ocho páginas (30-38); su actitud, sin embargo, por el momento recuerda más a las fábulas de Samaniego que al Quijote, en tanto que reitera una actitud tópica, de «hacer castillos en el aire», muy criticada por los ilustrados ${ }^{16}$. Con todo, hasta el momento resulta complicado hablar tanto de un personaje «loco» como de alguien simplemente ridículo, al igual que el resto de los «quijotes» habidos en las novelas de la época ${ }^{17}$. Los dos siguientes capítulos (62-112), sin embargo, contribuyen a singularizar algo más al personaje principal al introducir un elemento de capital importancia en la novela: la hierba mora, sustancia que supone un estímulo terminante a su alocada imaginación ${ }^{18}$, y que lo aboca a recrearse con la contemplación de realidades imaginarias:

$\mathrm{Y}$ en saliendo de esto, amigo, reparé que mi cama se empezaba a menear: ocurrióme luego que sería que la hierba pasaba ya a causar el efecto superior, y era la verdad. Al instante vi en cada pie de cama un buitre de tremenda magnitud: y luego viéndome en esa misma cama por los aires, y el lugar en un valle muy profundo, me eché a reír y me acordé de ti. [...] Pero chico, duró poco, porque pasado cuarto y medio, ya llegamos a un lugar famoso, apartado de este noventa y siete leguas y tres pies. [...] Yo me quería despedir; pero dije no, con un poco más de tiempo y coyuntura, puedo acrecer mi gremio y hermandad de la industria superior. ¿Y qué hice? Empecé a hablarles muy afable, y conociendo presto que era gente mansa y bien nacida, viendo también que se me iban inclinando muy formales, les di por fin modos sencillos de hacerse hábiles sin estudio, y de vivir $\mathrm{y}$ enriquecerse sin trabajar (96-109).

Supone, en términos de Ingarden, un «lugar de indeterminación» $(1989,37)$ el dilucidar si estas visiones se deben a alucinógenos, a su locura o a su sola

16. Recuérdense, por ejemplo, los siguientes versos de Samaniego: «Cuántos hay que teniendo lo bastante / enriquecerse quieren al instante, / abrazando proyectos / a veces de tan rápidos efectos / que sólo en pocos meses / cuando ya se contemplaban marqueses, / contando sus millones / se vieron en la calle sin calzones!» (2009, 333-334).

17. Ni siquiera puede considerarse locura el que, en ese mismo capítulo, el tío Gil confunda un grupo de lobos con unos espectros. Algo similar ocurre, por ejemplo, en el Eusebio de Montengón, en un pasaje en el que su protagonista escucha ciertos ruidos que, aunque provenían de su mascota, imagina que son causa de un fantasma (Montengón 1998, 168-172). El descrédito de la superstición era algo habitual en la literatura de aquellos años, y no por ello significativo.

18. Los efectos de esta extraña sustancia no están del todo claros, y el narrador se muestra en todo momento ambiguo al respecto, como más adelante detallaremos. 
imaginación ${ }^{19}$; lo cierto es que el tío Gil, en lo que acabamos de citar, muestra poder «transportarse» a realidades en las que tienen lugar acontecimientos sobrenaturales, como los buitres tirando de su propia cama; realidades en las que, además, él es admirado y venerado. En ese sentido, podemos observar que ya trasciende el estereotipo de curandero egocéntrico y algo supersticioso; su fantasía va más allá. Ya era abundante el detallismo que nuestro héroe proporcionaba a la hora de referir con minuciosidad la vida que planea tener; que este detenimiento sea igual o mayor a la hora de describir sus supuestas experiencias sobrenaturales nos permite advertir que el tío Gil vive en una realidad completamente distinta a la que es concebida por el resto.

Podemos percatarnos de que Francisco Vidal y Cabasés se ha servido de uno de los rasgos de don Quijote que no solían aprovechar apenas los imitadores cervantinos contemporáneos a la novela que estamos analizando, esto es, su capacidad para imaginar con base en sucesos que exceden los límites de lo posible; así, los «quijotes» de la España dieciochesca se caracterizaban por su percepción distorsionada o poco realista, pero sus ilusiones, por risibles que fueran, se mantenían siempre en el plano de lo naturalmente posible.

Adviértase que el tío Gil no es muy distinto de los otros «quijotes» durante los dos primeros capítulos, pero no es hasta el tercero y el cuarto que logra acercarse al de Cervantes tal como lo podían entender Jovellanos o Vicente de los Ríos. Esto, en los siguientes, se desarrollará aún más. Hasta el capítulo quinto, nuestro héroe todavía no se ha mostrado al resto del mundo; hasta ese momento, solamente se ha relacionado con la gente de su aldea, que ya lo conocen, y con su criado Blas. Pero, en su primer contacto con el exterior, comienza a hablar de la supuesta magia que dice poseer, y su falta de juicio se evidencia cuando se refiere a su vergajo como «una varita de virtudes admirable», que «removiendo los humores y el calor interno, en breve tiempo aumenta las potencias y la astucia» (120). Su locura queda confirmada cuando lleva a la práctica su «hechicería»:

De este modo algo raro, muy juntitos, el maestro Gil empezó a hablar en moro o jerigonza, y al instante a darles irritantes azotazos, y en cada uno les ponderaba grandemente su virtud. Quejábanse los pelaires; pero por las razones del maestro no dejaban de sufrir. ¡Cómo que no!, respondió el maestro Gil muy alterado, ¿os voy a serrar las piernas, majaderos? Si yo no pido, ni consiste en otra cosa, que en dar cuatro golpecillos, para remover la sangre, hacerla salir hasta los poros, y chuparse y entrarse luego la virtud, que en este cabo está (123-125).

Mientras que los protagonistas de otras imitaciones cervantinas eran estereotipos satíricos ${ }^{20}$ que poseían alguna actitud ridícula y perniciosa para la

19. Tal indeterminación da lugar a lo que, para Todorov, es «la primera condición de lo fantástico», o sea, «la vacilación del lector» $(2016,38)$. Más adelante matizaremos detalles al respecto.

20. Tal adjetivo debe entenderse aquí en un contexto dieciochesco. Si bien lo satírico, en la época de Cervantes, se asimilaba como lo que, aparte de ser cómico, está «sujeto a las prescripciones 
sociedad. En esa clase de obras, por lo general, sus respectivos autores consideran que no hay suficiente conciencia crítica contra lo que en cada caso toman por objeto de chanzas, y por ello resulta necesario crear una novela explicándolo. Sin embargo, en el pasaje que acabamos de ver de El tío Gil Maтисо, las consecuencias dañinas del comportamiento que se satiriza son más que evidentes, y lo serían igualmente en el caso de que existiera un personaje así en la vida real.

En los dos primeros capítulos el comportamiento del héroe es nocivo, y podía ser representación, aunque exagerada, de ciertos referentes reales y costumbristas de la época; en el tercero, sin embargo, el tío Gil actúa de un modo que raya en lo más exageradamente grotesco. Su obsesión con lo mágico no solo lo lleva, como a fray Gerundio, a predicar necedades sin provecho; además de eso, lo induce a agredir a personas inocentes hasta el punto de llegar a unos límites muy crueles, puesto que sinceramente piensa que quien está recibiendo los golpes puede lograr alguna clase de beneficio mágico de todo ello.

En el siglo XVIII todavía proliferaban curanderos que se valían de recursos poco empíricos que resultaban más perniciosos que benéficos para la sociedad (Perdiguero Gil 1996); una exageración hasta lo esperpéntico podía rayar en un pasaje como este, si bien suponía ya una desviación total de nada que pudiera tener un referente en la realidad. Capítulos posteriores vienen a demostrar que el personaje del tío Gil trasciende lo puramente satírico en tanto que el narrador presta más atención a sus peculiaridades que a los rasgos que puede haber tomado de exagerar a los curanderos reales.

Ya en el octavo, el protagonista se ensaña con un hombre cualquiera, al que agrede brutalmente sumido en el más profundo delirio: «¿Temes, cabrón, por ventura a los pendientes del coral, a la raíz de la aristológica, que ahuyenta a los diablos, y a otros simples que aquí traigo? Pues aún te queda este invencible y tremendo brazo que probar» (168-169). Así, «descargó sobre el cerril tanta multitud de espaldarazos con tal espíritu y enojo, que no pudiéndolas sufrir el infeliz, se dejó caer» (169); en ese momento aprovecha el tío Gil para predicar sus propias virtudes, lo que añade un matiz aún más anómalo a la escena:

Aquí tenéis, y no penséis que es bola, al que tiene maña para hacer huir a los ínfimos demonios, y deshacer cuantos hechizos y hechiceras quieran hacer el mal, y vengan, aunque sea bajo la capilla de san Gil. [...] Aquí tenéis al que se hace invisible cuando quiere y urge, valiéndose de un simple y natural arcano, como lo jurará este chico mío, siempre que sea menester. Aquí tenéis al que por una receta grande y prodigiosa que conserva, en un brazo solo, tiene más fuerza y osadía que treinta granaderos

canónicas relevantes» (Close 2007, 395), en el siglo XVIII, no obstante, implicará un tipo de humor opuesto al que estaba basado «en el principio de la tendencia al bien» (Rivero 2011, 149); más adelante, al referirnos a El tío Gil Mamuco como una novela más burlesca que cómica, matizaremos lo que esto suponía. 
en los dos. Aquí tenéis al que sabe cómo se ablandan las tempestades del mar y la tierra. En fin, aquí tenéis al maestro y corregidor universal, quien posee y guarda arbitrios fáciles y probados (180-181).

Nuestro héroe ya no es la exageración grotesca de un problema social, sino que se ha convertido en un percance en sí mismo, en algo anómalo, sin equivalente imaginable; demuestra estar loco, tal como Jovellanos o Vicente de los Ríos pudieron entender a don Quijote. Las continuas alabanzas que se hace mientras que su víctima yace inconsciente en el suelo son una clara prueba de esto; su desmesurado ego no es consecuencia de ningún mérito o reconocimiento real, sino de una percepción completamente errónea de sí mismo, basada, fundamentalmente, en una fe ciega hacia sus presuntas habilidades mágicas.

Su locura llega hasta el punto de sentir total indiferencia ante las vejaciones que él mismo recibe, puesto que su distorsión de la realidad es tal que termina por negarla de manera total; así, el capítulo IX (189-215) concluye con el tío Gil recibiendo una brutal agresión a manos de unos quintos, mientras que en el X (215-250) decide deleitarse una vez más con «hierba mora», y así poder contemplar a sus agresores inclinarse ante él y reconocerlo como su maestro. La negación absoluta de la realidad empírica, presente ahí, será lo que predomine en la aventura del castillo (250-371), que tiene lugar en los tres últimos capítulos ${ }^{21}$.

Estos son los postreros delirios del tío Gil antes de ser apresado por la justicia; que en ellos su locura sea igual o superior a la que tiene en los primeros capítulos implica que no pueda haber posibilidad de recobrar el sentido común para un personaje así. Dicha locura, en el universo ficcional de la novela, resulta totalmente verosímil; un ilustrado como Vidal y Cabasés, autor de libros de carácter científico, nos presenta un mundo regido por la razón y las leyes empíricas, una sociedad en la que no tienen cabida de ningún tipo los curanderos, los magos, los alquimistas y los charlatanes en general. Alguien como el tío Gil, por ello, será necesariamente repudiado por la sociedad, y solo el irracionalismo y la locura le permitirán continuar hacia delante, porque, de regirse por la razón o el sentido común, hubiese acabado trocando su profesión por alguna carente de relación con la magia. Puesto que se siente totalmente incapaz de ceder a los intereses sociales, será la propia sociedad la que acabe deshaciéndose de él; por ello, como ya vimos, la novela finaliza con el encarcelamiento de nuestro héroe (370-371).

\section{EL TRASFONDO ILUSTRADO}

Adviértase que, pese a las similitudes con el Quijote -o, mejor dicho, con una interpretación muy concreta de la obra cervantina-, el trasfondo de la obra

21. En estos confunde una antigua fortificación con un palacio, y a una cabra con la presunta señora del lugar, de la que acaba enamorándose. 
responde a lo habitual en el XVIII español, en tanto que aquí también se le da «un sentido utilitarista a la expresión artística» (Álvarez Barrientos 1991, 13). Esta mentalidad utilitarista que tanto imperaría en el Siglo de las Luces se explica si atendemos a la secularización de parte de la sociedad, lo que se traduciría en nuevos conceptos de «moral» y «virtud»; la primera, así, pasa a ser una «norma de conducta», y la segunda sería sinónimo de «utilidad social» (Álvarez Barrientos 1991, 112). Contexto muy diferente fue el de la fecha en la que apareció la novela de Cervantes; aparte de que «virtud» y «utilidad» aún no eran sinónimos, la sociedad todavía no tenía asumidos ciertos principios básicos con respecto a las ciencias naturales, y la «magia» todavía no había sido del todo desterrada del sistema de creencias imperante ${ }^{22}$. La presunta locura ${ }^{23}$ que demuestra don Quijote, de hecho, no se basaría tanto en una percepción errónea de la naturaleza, sino de la sociedad. El caballero de la triste figura puede parecernos loco por afirmar que en su sociedad hay cabida para los caballeros andantes, estamento social que había desaparecido años atrás; su obsesión por los hechos heroicos lo llevaría a transformar la realidad, y a pretender encontrar aventuras donde no las hay. Aparecen, por ello, muchos personajes que rechazan las novelas de caballerías como documentos empíricos, pero no aparece ninguno que muestre ese mismo descreimiento hacia los libros de «ciencias naturales» que antes hemos mencionado; esta clase de supersticiones, mezcladas con las ciencias entonces tenidas por reales, se habrían de prolongar durante el propio siglo XVIII.

Pensemos, si no, en la figura de Torres Villarroel, intelectual relacionado con todos los asuntos esotéricos habidos y por haber, conocido, entre otros motivos, por su labor astrológica en sus almanaques; en su autobiografía, de hecho, se refiere a varias «ciencias» en las que está interesado, a saber, «la Filosofía natural, la Crisopeya, la Mágica, la Transmutatoria, la Separatoria y, finalmente, paré en la Matemática» (Torres Villarroel 1998, 159). Este fragmento de la Vida de Torres pertenece al trozo tercero de la misma, que vio la luz en 1743; para esa fecha, por tanto, la superstición andaba confundida con la ciencia empírica, y, como acabamos de ver, la física y las matemáticas quedaban entremezcladas con disciplinas tan poco científicas como la magia y la alquimia. Lo cierto es que para 1789, fecha de la publicación de El tío Gil Maтисо, los ilustrados habían hecho lo posible por desterrar lo sobrenatural de las creencias de las personas (Roas 2006, 20-24); alguien que se obstinara con seguir manteniendo esa fe a pesar de las evidencias empíricas

22. Pensemos, si no, en algunos libros sobre esta materia relativamente cercanos en fechas a la novela de Cervantes, a saber: Silva de varia lección (1540), Jardín de flores curiosas (1570), Disquisitionum magicarum (1600) y El ente dilucidado (1676); todas ellas obras en las que la magia y la ciencia se entremezclan, puesto que sus autores no se muestran capaces de distinguir lo uno de lo otro (Roas 2006, 18-19).

23. Es bien conocida la interpretación que de la obra cervantina hace Torrente Ballester en El Quijote como juego (1975), según el cual la «locura» de don Quijote no sería sino un fingimiento, un artificio lúdico planificado racionalmente por Alonso Quijano. Dado que no es labor de este trabajo desmentir o reafirmar tales afirmaciones, nos referiremos a la «locura» de don Quijote como algo en todo momento presunto, a diferencia de la del tío Gil, que no deja lugar a tantas dudas. 
que lo desmienten habría de ser una persona completamente irracional, en el más puro sentido de la palabra, porque estaría yendo directamente en contra de la razón y del empirismo ${ }^{24}$.

Ni siquiera podemos decir que don Quijote sea irracional en ese sentido; su supuesta locura viene, principalmente, de su voluntad y de su obstinación lúdica por buscar aventuras caballerescas en un mundo que no las proporciona, pero no de su sistema de creencias sobre la naturaleza. La locura del tío Gil, sin embargo, viene dada, fundamentalmente, por considerarse capaz del ascenso social, hasta el punto de quedar eximido de tener que trabajar, gracias a la magia e «industria superior», en las que mantiene su fe pese al descreimiento habido en el XVIII, no existente de ese modo en el siglo anterior, y a pesar también de que las constantes evidencias con las que se va encontrando desmienten tal supuesto. Así, las aventuras eran el principal objetivo de don Quijote, a las que este siempre tiene acceso pese al nefasto fin de la gran mayoría; las peripecias del tío Gil, en cambio, son solo un medio para lograr lo que pretende desde el principio de la obra, el mencionado premio, que nunca le es concedido. Que tal galardón sea real o no es otro «lugar de indeterminación» de la obra, pero, incluso aunque asumiésemos su existencia, tendríamos constancia de que el protagonista de la novela no se lo merecería, por no haber aportado, en realidad, nada útil a su sociedad.

Al comienzo del Quijote, Alonso Quijano se nos presenta como un hidalgo al que no le falta el dinero y que no vive del todo mal; la «profesión» de caballero andante será algo que adopte más adelante, y no lo hace movido por fines económicos. El tío Gil, sin embargo, se dedica a cuestiones esotéricas desde el comienzo de la novela; nos es presentado como «un curandero algo falto de caletre» que «con las curas no medraba», por lo que acaba poniendo una tienda en la que vendía «peines, chiflas de caña, papel de estraza, sartas de hebillas, ligas de moda, punzones gordos, medallas nuevas, candiles negros y otras cosillas de poco valor» ${ }^{25}$; esta tienda, sin embargo, tampoco le da demasiado dinero, por lo que «dependía el sustento de la casa del buen Blas» (1-2). Después de eso, se dedica a buscar la piedra filosofal, tentativa en la que falla y acaba lanzándose por ese supuesto premio; en ningún momento, a diferencia de lo que ocurría con don Quijote, se puede decir que haya cambiado esencialmente su ocupación principal, puesto que el tío Gil siempre se dedica al esoterismo, aunque lo haga por diferentes vías. En cambio, según la mentalidad que aquí demuestra Vidal y Cabasés, la sociedad de 1789 ya no

24. En el siglo XVIII, la razón «se convirtió en el paradigma explicativo fundamental, lo que se tradujo en una separación entre razón y fe, dos perspectivas que [...] hasta ese momento funcionaban integradas, o, por lo menos, no se excluían entre sí» (Roas 2006, 20-21). En la Ilustración española, tal racionalismo estuvo profundamente influido por un empirismo cientificista entendido a la manera de Roger Bacon, que sería defendido por autores como Feijoo (Fernández 2006, 630).

25. Podemos entender que el poco valor de algunos de esos objetos se basa en su carácter esotérico y en que la utilidad empírica de los mismos es más bien poca. No ocurre así, sin embargo, con lo que fabrica Blas, «cajas, lamparillas, abanicos, jaulas, hebillas, pendientes, ratoneras, bragueros y relojes de madera» (2), objetos realmente útiles para la sociedad, que acaban siendo el sustento fundamental de la casa. Adviértase, una vez más, el utilitarismo presente en la filosofía de la novela. 
da cabida a los charlatanes que se dedican a la magia; por ello, individuos como el tío Gil son innecesarios; tanto da lo que intenten, porque no van a recibir reconocimiento social de ningún tipo mientras no se dediquen a menesteres más útiles.

La magia en la novela es algo que solo beneficia al propio tío Gil, porque le permite vivir de ello, pero no causa ningún bien al resto de los personajes; la magia, por ello, entra en el terreno de «lo individual» y es rechazada del de «lo social» por no suponer ninguna utilidad. El protagonista, sin embargo, se niega a ceder ante las presiones sociales, y se obstina en continuar dedicándose a lo esotérico a pesar de su carácter inútil; actitud ya no solo irracional, sino que implicaría priorizar los intereses de personas concretas frente a la sociedad.

La perspectiva del tío Gil está, sobre todo, centrada en el individuo, y considera a las personas «superiores» o «inferiores» en función del esfuerzo real que hagan; aquellos que, como él, se dediquen a menesteres en los que no haya que hacer prácticamente nada productivo habrán de pertenecer a la «industria superior», porque pueden recrearse en el descanso y en el bienestar. Por el contrario, las personas que realmente hagan una contribución significativa a la sociedad son parte de la «baja industria», puesto que las contribuciones sociales implican sacrificar descanso y comodidad:

El objeto de la industria superior, por mí inventada, es, y quiero que haya de ser siempre, lo más profundo, lo más eminente, y lo más ganancioso que se pueda discurrir; con el supuesto, que ha de ir todo acompañado del requisito del descanso, recreo y pundonor. [...] Con que, durísimo se me hace, que ni aun por diversión, se hubiesen querido deslustrar, con ese oficio mecánico, negro y vil. Mas, que sé yo por experiencia, que por lo común las gentes quieren empleos decorosos, nada fatigosos, una industria superior, una cucaña, que les enriquezca, sin tener nada que hacer, procurándoles honor, gozo y sanidad; y ésta es la mente del señor, que ha de dar el premio del millón.

¿Pues no dijeron en la tienda, replicóle Blas, que por premática del rey, se hayan ya las artes nobles, aunque sean feas y podridas las materias? Y ahora que me acuerdo, ¿no lo confirmó también el cojo del correo, diciendo, que solo quedaban sin honor, los mancebos y maestros, por los puros hechos de robar, seducir, de levantar las manos a sus padres, y de perder las doncellas del país? (261).

La exaltación del tío Gil se hace ridícula ante las palabras de Blas, que señala cierta «premática del rey» ${ }^{26}$ según la cual cualquier oficio es noble, por muy desagradable que sea su ejecución, una mentalidad, desde luego,

26. Dicha premática no está haciendo referencia a ningún rey real ni a ningún acontecimiento histórico como tal; la novela, de hecho, no se desarrolla en ningún país concreto, sino en un territorio más bien indeterminado e imaginario, «en un país alegre y población famosa, cuyos nombres callo por motivos graves y mandamientos que venero» (1). No obstante, dicha «premática» puede hacer alusión a los avances ideológicos en justicia social de la época. 
pragmática e ilustrada ${ }^{27}$ que no establece más jerarquía que la de la utilidad social de cada individuo. Por ello señala que solamente deben considerarse «sin honra» aquellas personas, como los seductores de doncellas, que hagan algún daño a la sociedad, pero los individuos que se dedican a trabajos desagradables deben ser tenidos por gente respetable por dedicarse a menesteres útiles.

No es casual, a este respecto, que una obra como El tío Gil Mamuco se haya publicado en 1789; fecha que coincide, por cierto, con la revolución francesa, y con un escrito de capital importancia: nos referimos a ¿Qué es el tercer estado?, de Sieyès, texto que parte del utilitarismo para proponer un replanteamiento de las jerarquías establecidas hasta el momento. Este autor es seguidor de las corrientes de Voltaire en las Cartas filosóficas y de Jeremy Bentham, por lo que considera que «el argumento de utilidad es el más necesario para que una nación exista y prospere» (Figueras Pàmies 1989, 226). En consecuencia, entiende, al igual que Blas Peguín en el fragmento que acabamos de citar, que resulta absurdo que las personas que trabajan tengan peor reputación precisamente por trabajar: «¿Qué país es ese en el que el trabajo deshonra, en el que es honorable consumir y humillante producir, en el que a las profesiones duras se las llama viles, como si pudiera haber algo más envilecedor que el vicio, y como si esa vileza, la única real, existiera entre las clases trabajadoras?» (Sieyès 2016, 129). En España se defendieron ideas muy similares en obras como Eusebio de Montengón, en un fragmento puesto en boca de Jorge Hardyl ${ }^{28}$ (Montengón 1998, 119), muy similar al que Vidal y Cabasés pone en boca de Blas Peguín; podemos decir que ambos textos son relativamente similares en lo estilístico, puesto que ambos son exordios morales que vendrían a ensalzar la importancia del trabajo físico a partir de su utilidad. No obstante, y a pesar de las similitudes de estilo, tenemos que apreciar una diferencia fundamental en cuanto al uso de estos exordios entre un autor y otro. En el Eusebio de Montengón, discursos así eran lo más importante de la novela; la trama argumental, de hecho, no era más que una simple excusa para que el autor, por boca de Hardyl, pudiera sermonear moralmente a los lectores. En El tío Gil Maтисо, sin embargo, los exordios morales son importantes, pero no son el núcleo de la novela; su principal objetivo no es tanto moralizar al lector, que también, sino evidenciar lo pernicioso del comportamiento del tío Gil para acentuar su carácter grotesco. Por

27. En este caso, con «mentalidad ilustrada» aludimos, sobre todo, al conjunto de ideas de carácter humanista y utópico que afloraron en el XVIII, a saber, «la confianza en el poder de la razón, la fuerza de la naturaleza, la fe en la ley del progreso, la credulidad en la felicidad terrena como posible y el optimismo de que estas pueden generalizarse; además, el sentido de la utilidad, la dimensión humanista, la defensa de una religión natural o la defensa del secularismo son otros contenidos a los que debemos añadir la tolerancia, la defensa de la educación formal, el debate y la difusión propagandística de los contenidos citados» (Blanco Martínez 2004, X). La idea presente en El tío Gil Maтисо relativa a valorar a las personas en función de lo que aporten a la sociedad implica una clara afinidad con esta cosmovisión en la mayor parte de sus características.

28. En la novela de Montengón, Hardyl es el maestro del protagonista, una herramienta de la que el autor se sirve para dar numerosas lecciones morales a sus lectores. 
ello es muy diferente el estilo del protagonista respecto al del narrador; este último, a diferencia del personaje, muestra una focalización cero, una voz heterodiegética, y narra desde un nivel extradiegético ${ }^{29}$, lo que le permite, lejos de mostrar el más mínimo entusiasmo ante la magia, insertar burlas hacia su personaje siempre que puede: «Es cosa muy difícil descubrir las verdaderas causas y razones, que mueven a estas ocurrencias, o aquellas acciones disparatadas que ejecutan los pobres mentecatos») (80, la cursiva es nuestra); «Otros muchos desvaríos dijo a la moña el tío Gil» (324, la cursiva es nuestra). En este sentido, el narrador es muy similar al del Fray Gerundio del padre Isla.

El contraste de estilos que implica, sobre todo, el cambio de nivel y de focalización, es lo que permite al autor alejarse del mundo interior del tío Gil, presente en su intradiégesis y focalización interna, para demostrar lo irracional y absurdo de sus ideas; el exordio moral y la sátira posibilitados por el nivel extradiegético, muy propios de la Ilustración, sirven de freno a una mentalidad que se venía arrastrando desde la época de Torres Villarroel. Pero el hecho de que todo ello esté subordinado a lo lúdico supone una distancia respecto a otras obras de la Ilustración, como el Eusebio, en las que el contenido moral suponía el núcleo de la novela; todos los otros elementos contenidos en la narración venían, de hecho, subordinados a ello. En El tío Gil Матисо, por el contrario, lo moral no se convierte tanto en el elemento principal de la composición, sino en una parte de esta; su finalidad es, fundamentalmente, la de componer un texto esencialmente divertido, y más burlesco que cómico ${ }^{30}$, en el que el humor, muchas veces de carácter grosero, no venga a ser truncado por el exceso de moralidad.

El tema escogido favorece la amenidad del relato frente a otras novelas de la época. Esta narración es, ante todo, una que trata sobre la locura de un hombre que niega todo tipo de razonamiento empírico en favor de la magia

29. Por «focalización cero» entendemos un «relato con narrador omnisciente» con «visión por detrás»; a ello se le opondría la «focalización interna» del tío Gil, ya que, cuando este toma el relevo narrativo, lo contado pasa a ser un «relato con punto de vista, con omnisciencia selectiva, con restricción de campo» (Genette 1998, 46). Con voz «heterodiegética» nos referimos a que el narrador principal «no es responsable de la información», porque «la "omnisciencia" forma parte de su contrato»; el tío Gil, en cambio, posee una voz «homodiegética», en tanto que está «obligado a justificar [...] las informaciones que da sobre las escenas de las que ha estado ausente como personaje» (Genette 1998, 54); justificaciones que, en este caso, a Blas le resultan insuficientes por inverosímiles. A su vez, consideramos que el narrador principal está a un nivel «extradiegético» en tanto que se encuentra «a la misma altura [...] que el público», mientras que el del tío Gil sería «intradiegético», porque es «un personaje dentro de un relato que no es el suyo» (Genette 1998, 58).

30. En la época de Cervantes, se entendía por «cómico» todo aquello que, en el arte, «aspira a purgar las emociones a través de la risa» (Close 2007, 99). Pero, como ya adelantamos anteriormente, en el XVIII lo «cómico» pasó a entenderse, dentro del humor, como oposición a lo «burlesco», como queda explicado por Rivero Iglesias, quien refiere que el primero es un tipo de humor mucho más amable que el segundo; así, mientras que a lo «burlesco» se asociaba lo «humillante», «ridículo», la «burla», la «caricatura» y lo «afectado», lo «cómico» será algo mucho más «benevolente», «risible», asociado a la «risa», al «retrato» y a lo «natural» $(2011,151)$. Lo grotesco y caricaturesco en el El tío Gil Mamuco, tanto en el protagonista como en sus aventuras relatadas, nos impiden considerarla una obra «cómica» según esta acepción, por lo que resulta más adecuado entroncarla en lo «burlesco». 
o la fe ciega en cuestiones inverosímiles. Las ocasiones en las que el tío Gil delira son muchísimas y significativamente extensas; estos delirios, en sí mismos, no tienen tanto una finalidad moral, sino que contribuyen a entretener al lector exagerando el carácter cada vez más grotesco del protagonista. Reparemos, si no, en las palabras del propio autor en el prólogo de la narración, quien afirma haber elaborado la obra con el objeto de que fuera de «interés y pro», pero confiesa, con relación al resultado, que «de algún interés o diversión confío, pero de ninguna pro» (III); es decir, ya entonces afirmaba haber escrito una obra centrada más en entretener que en enseñar, aunque su finalidad abarcara tanto lo uno como lo otro.

Dado que, como ya explicamos, la concepción del mundo de los ilustrados tomaba el empirismo y lo racional como base, obstinarse en perpetuar la creencia en la magia habrá de conllevar irracionalismo y, por ende, locura. No obstante, esta locura nos es presentada como fuente de entretenimiento, puesto que, si bien no tiene ninguna utilidad social evidente, puede llegar a causar bastante diversión en quienes la contemplan. La mentalidad ilustrada, a cuyas características ya nos referimos, supone, por tanto, la base ideológica de la obra, si bien se diluye en sus múltiples páginas en favor de lo puramente lúdico.

\section{LA «HIERBA MORA»Y LOS PARAÍSOS ARTIFICIALES}

La interpretación de la mayoría de los sucesos de la novela es completamente clara y unívoca: el tío Gil está loco, y a partir de su locura acaba delirando e imaginándose tantas fantasías. No obstante, hay una excepción bastante sutil: nos referimos, esencialmente, a los pasajes en los que adquiere una relevancia capital la hierba mora, que, como señalamos, presentaban un claro caso de indeterminación.

Como ya anticipábamos, la hierba mora es el único sortilegio del tío Gil cuya inutilidad no es completamente evidente. En todos los pasajes en los que nuestro héroe se sirve de dicha droga, siempre afirma haber sido transportado a todo tipo de lugares extraños, en los que le ocurrían sucesos verdaderamente insólitos. La interpretación de que el tío Gil literalmente haya sido transportado hasta todos esos lugares queda completamente descartada desde un primer momento; como bien señala Blas, «usted no se ha movido del sitio donde se tumbó: yo he divisado a usted y la campaña cada cuarto de reloj; que no he dormido en toda la noche de Jesús» (79). No obstante, una vez descartada esa interpretación, sería incorrecto afirmar que solo queda una única posible, como ocurre con el resto del pasaje.

$\mathrm{Si}$, siguiendo a Ingarden, asumimos que pasamos «por alto los lugares de indeterminación en cuanto tales e involuntariamente rellenamos muchos de ellos con determinaciones no justificadas por el texto» $(1989,38)$, observaremos que, habiendo descartado la realidad del aludido viaje, quedarían al 
menos tres lecturas posibles, tres vías por las que «rellenar» lo que en ningún momento se clarifica: la primera consistiría en que el tío Gil se haya inventado todos los sucesos que asegura haber visto con la hierba mora. La segunda, en que haya tenido alucinaciones a partir de su locura y su sugestión. La tercera sería la más interesante de todas, y supondría asumir que la «hierba mora» no es en realidad una sustancia con propiedades mágicas, sino psicotrópicas y alucinógenas.

Debemos tener presente que en ningún caso es el suceso sobrenatural una lectura posible, por lo que no sería lícito hablar, sensu stricto, de «literatura fantástica» en esta novela; no obstante, el modo en el que se presentan tales acontecimientos tiene un funcionamiento muy similar al de lo fantástico, y encajaría con lo que Todorov denomina «extraño», en tanto que «las leyes de la realidad quedan intactas y permiten explicar los fenómenos descritos»; en concreto, pertenecería al terreno de lo «extraño puro» ${ }^{31}$, ya que «se relatan acontecimientos que pueden explicarse perfectamente por las leyes de la razón, pero que son, de una u otra manera, increíbles, extraordinarios, chocantes, singulares, inquietantes, insólitos y que, por esta razón, provocan en el personaje y el lector una reacción semejante a la que los textos fantásticos nos volvió familiar» $(2016,54)^{32}$. Tal reacción, en este caso, viene dada por la ya mencionada indeterminación, en tanto que resulta inquietante y enigmático un interrogante que no se termina de resolver: ¿es la hierba mora realmente otro sortile-

31. Todorov introduce este matiz para diferenciar lo «extraño puro» de lo «fantástico-extraño», o sea, cuando los sucesos «que a lo largo del relato parecen sobrenaturales, recibe, finalmente, una explicación racional» $(2016,52)$. Dado que en El tío Gil Mamuco el protagonista demuestra estar loco, de lo cual el lector tiene plena consciencia, las experiencias con la hierba mora nunca llegan a parecer sobrenaturales realmente. Bien es cierto que el mismo Todorov considera que las sustancias psicoactivas pueden dar lugar, en literatura, a esto mismo mediante lo «real-ilusorio» $(2016,53)$, y podemos encontrar ejemplos de ello en varios relatos de Gautier (2020), en los que la acción se dispone de modo que el lector pueda dudar de la realidad de lo narrado, pese a que los personajes hayan consumido drogas; sin embargo, el tono burlesco de El tío Gil Mamuco y la constatada locura inicial de su protagonista, que carece de credibilidad alguna para el lector, nos impiden siquiera considerar esa posibilidad. El mismo Todorov incide sobre cómo quien narra puede condicionar al receptor para dar más o menos credibilidad a lo relatado; así, mientras que un personaje, como el tío Gil, «puede mentir, el narrador no debería hacerlo» $(2016,93)$. En este caso, ya no solo asumimos que el personaje «miente» en esta parte, sino que lo hace a lo largo de toda la novela, en tanto que no demuestra comprender correctamente la realidad debido a su falta de juicio.

32. La preferencia, en este caso, por lo «extraño puro» pudo haber estado condicionada, en parte, por las preceptivas ilustradas que imperaron en el XVIII en España. Por ejemplo, Luzán, en su Poética, comprende y aprueba que la literatura deba, por lo general, adentrarse en el terreno de lo extraordinario, pero solo ve recomendables tales atrevimientos si se mantienen verosímiles: «El juicio, para guiar y regir sin tropiezo la fantasía, debe, primeramente, examinar y discernir la proporción de las imágenes, aprobando solamente aquellas que sean verisímiles, proporcionadas y moderadas, y desechando las que parezcan improprias (sic), desproporcionadas y muy arriesgadas» $(1977,279)$. La introducción de elementos claramente fantásticos, en los que tuviese cabida la interpretación sobrenatural, rompería, en este caso, la verosimilitud de un relato que se basa, sobre todo, en lo burlesco. La figura del tío Gil es grotesca porque está loco y distorsiona la realidad; si se abriese la posibilidad de que sus supuestos delirios son reales, podría quedar sugerido que no ha perdido del todo el juicio, lo que supondría una clara contradicción con el resto de la novela, en la que el autor pretende constantemente aseverar la degeneración mental del protagonista. 
gio inútil, como el resto de los que el tío Gil muestra a lo largo de la novela ${ }^{33}$, o tiene esta vez alguna propiedad, aunque psicotrópica, real?

Hay una ocasión en la novela en la que el autor parece indicar que no existe tal ambigüedad, y que solo hay una única interpretación para los delirios del tío Gil con la hierba mora: la primera, esto es, que es todo pura invención. Nos referimos a un momento del capítulo $X$ en el que el narrador afirma que todas las visiones que nuestro héroe asegura haber tenido las ha sacado a partir de un viaje a Madrid que tuvo hace poco, en el cual se inspiró para relatarle a Blas todo ello (243-244). No obstante, en ese caso el narrador solamente se refiere a los delirios que el tío Gil tiene con la hierba mora en ese mismo pasaje. Dentro del mismo capítulo $X$ hay otro suceso con esa sustancia (246-249), del cual el narrador no establece ningún juicio interpretativo. Hay, además, otras dos escenas de la novela en las que nuestro héroe se sirve de la sustancia sin que el narrador afirme nada al respecto; nos referimos a las de los capítulos III (68-79) y IV (94-109). En el III, de hecho, hay una reflexión sobre la ambigüedad de las visiones del tío Gil.

El narrador, sirviéndose de cierta omnisciencia editorial a partir de un vecino que hace las veces de Cide Hamete Benengeli, comienza a conjeturar, y parte de la evidencia de que el tío Gil no se transportó a ningún sitio real para formular posibles hipótesis sobre por qué nuestro héroe aseguró haberse trasladado a semejantes lugares (80-82). Atribuye las posibles causas de esto a su imaginación, sus sueños y su delirio; la posibilidad de que todo sea producto de alucinaciones causadas o sugeridas por la hierba mora no aparece formulada, pero tampoco se descarta de forma explícita. La ambigüedad con respecto a la hierba mora es real, y aunque en el pasaje del capítulo X parece tener una única interpretación, el fragmento que acabamos de citar nos permite comprender que, en el conjunto de la novela, todo lo relativo a la hierba mora tiene un carácter fundamentalmente vago; ambigüedad dentro de la que cabe, por supuesto, la posibilidad de que esta sustancia tenga un carácter verdaderamente psicotrópico, que sea lo que estimule su imaginación.

No sería, de hecho, disparatado ni inverosímil la presencia de una sustancia así en una obra de finales del XVIII. Para las fechas en las que se publicó la novela, el consumo de sustancias psicoactivas era algo que ya estaba parcialmente implementado en la sociedad (Luna-Fabritius 2015); a principios del XIX, de hecho, este asunto despertará especialmente el interés de los románticos, quienes dedicarán obras enteras a ello. Pensemos, si no, en las Confesiones de un inglés comedor de opio, de Thomas De Quincey (1822), o en El club de los hachisinos (1846), de Teophile Gautier. Dentro del XIX, pero más allá del Romanticismo, el célebre Baudelaire publicaría un tratado dedicado exclusivamente a esta cuestión: Los paraísos artificiales (1860), en los que se refiere al consumo de drogas como una especie de éxtasis divino.

33. Adviértase que, de ser así, tampoco estaría determinado si se debe a una «farsa», a pura mentira e imaginación por parte del tío Gil, o si es consecuencia de su enajenación mental, preexistente al consumo de alguna droga real o supuesta. 
En la literatura del XVIII español, lo más próximo a esto lo serían las obras de Torres Villarroel en las que la droga «aparece no solo atendiendo a su cualidad adormecedora, sino también como sustancia psicotrópica» (Escalante Varona 2019, 50). Dado que ese escritor, por su vinculación con lo esotérico, suponía un referente de la mentalidad que muchos ilustrados querían abolir ${ }^{34}$, no sería de extrañar que su vinculación con esta clase de sustancias haya sido un rasgo tomado por Vidal y Cabasés para configurar su personaje, que encarna las últimas consecuencias de llevar hasta el final presupuestos considerados irracionalistas.

Que realmente el autor pretenda sugerir la presencia de lo psicotrópico es algo que se acentúa si observamos cierto paralelismo entre la «hierba mora» y el opio en la obra de De Quincey: «Si un hombre "que solo habla de bueyes" se convierte en comedor de opio, lo más probable (a menos que sea demasiado obtuso para soñar) es que sueñe con bueyes, mientras que en el caso que tiene ante sí el lector encontrará que el comedor de opio presume de ser un filósofo» (De Quincey 2018, 20). Aquí el opio es concebido como una sustancia capaz de estimular los deseos y anhelos personales de cada individuo; con la hierba mora vendría a ocurrir lo mismo, porque al tío Gil le permite sumergirse más aún en una serie de fantasías que ya son bastante intensas sin necesidad de consumir ninguna sustancia. Y no nos estamos refiriendo únicamente al carácter sobrenatural de las visiones que nuestro héroe experimenta; mucho más importante que eso es la visión sobre sí mismo que la hierba mora le permite tener. Al fin y al cabo, la obsesión del protagonista a lo largo de toda la novela es lograr un reconocimiento social que jamás podrá obtener desempeñando una profesión tan inútil. Cuando ingiere de la hierba mora, sin embargo, se ve transformado en alguien de prestigio, admirado y reconocido por toda la sociedad.

En la primera ocasión de la novela en la que el tío Gil consume hierba mora, en el capítulo III, nuestro héroe afirma haberse transportado hasta la corte de Madrid, donde se presenta como el «marqués de los Mamucos» y es tratado como tal (69-79). Lo verdaderamente fantasioso de ese pasaje no son tanto las visiones que haya podido tener de la corte de Madrid, sino el hecho de que allí le hayan dado un supuesto reconocimiento como marqués, como alguien de prestigio; reconocimiento que, por cierto, en la vida real le es negado por completo. De igual forma, en las ensoñaciones del capítulo IV el tío Gil se encuentra con un hechicero, «el mágico blanco don Bausán», quien le muestra una profunda devoción y admiración, y lo anima a continuar con su empresa (106-107); en el capítulo X el asunto es aún más exagerado, puesto que la hierba mora le permite fantasear con convertir en sus discípulos a los mismos que, un capítulo atrás, le proporcionaron una brutal agresión (240-241).

34. Los pronósticos y predicciones de Torres Villarroel lo hicieron blanco de críticas y burlas por parte de intelectuales ilustrados como Feijoo o José Francisco de Isla (Martínez Mata 1998). 
De todas las alteraciones perceptivas que la hierba mora pudiese provocar en el tío Gil, consideramos que las más significativas son, precisamente, las relativas a la percepción que tiene de sí mismo. Es en ese narcisismo amplificado y en la autocomplacencia donde podemos observar una mayor similitud con el opio al que tanto se aficionó De Quincey; mientras a este último, como ya hemos visto, le permitía verse a sí mismo como un gran filósofo, al tío Gil la hierba mora le permite verse transformado en alguien de reconocido prestigio social. Las visiones exóticas y maravillosas que la droga le infiere no son tan importantes, porque no guardan tanta relación con sus deseos individuales; no obstante, lograr reconocimiento social de la forma que sea viene siendo la prioridad principal de nuestro héroe desde el comienzo de la novela, y la hierba mora le permite obtenerlo, aunque sea de manera ficticia.

Tampoco sería para nada disparatado que la existencia de una droga como el opio, posible trasunto de la hierba mora, fuese conocida por un intelectual ilustrado con grandes conocimientos sobre agricultura como lo fuese Francisco Vidal y Cabasés. De Quincey $(2018,15-16)$ hace referencia a un tratado de 1764, Ensayo sobre los efectos del opio, escrito por un boticario llamado Awsiter; si para 1764 ya se conocía algo sobre la droga y sus efectos, resulta coherente que pudiese inspirar una novela de 1789 .

El tío Gil utiliza la hierba mora para intentar evadirse de la realidad; al margen de que la hierba mora tenga o no efectos reales, la evasión sí que es real, puesto que el solo hecho de recrearse narrando sus fantasías supone otra forma de escapismo. Y es totalmente lógico que una persona como el tío Gil tenga este tipo de actitud; en el primer capítulo, como ya vimos, se habla de sus fracasos como curandero, como dueño de una tienda de artículos esotéricos y como buscador de la piedra filosofal, mientras que en el segundo capítulo es atacado por unos lobos. No es para nada de extrañar que los dos capítulos siguientes los pase recreándose en otras realidades superiores con la hierba mora; esto se hace, de hecho, mucho más evidente en el ya aludido capítulo X.

El tío Gil Mamuco, en ese sentido, enlazaría lo habido en Torres Villarroel con obras como las de Quincey, Gautier y Baudelaire, al dejar entrever la posibilidad del empleo de sustancias como método para el deleite y la satisfacción, lo que no suponía ninguna contradicción con respecto al ya aludido empirismo baconiano, dado que todas las alucinaciones provocadas por la presunta droga quedan concebidas solo como una realidad psicológica, inexistente fuera de la mente del protagonista. Al fin y al cabo, no hay un solo momento en el que el tío Gil salga victorioso de sus aventuras; no obstante, siempre que usa la hierba mora acaba viéndose convertido en un señor poderoso, respetado de todo el mundo e incluso de sus enemigos en la vida real. Tenga un efecto psicotrópico real o sea todo producto de la sugestión y de la imaginación del protagonista, todo parece apuntar a que el tío Gil utiliza de la hierba mora con fines muy similares a los que aparecen en De Quincey, Gautier y Baudelaire, esto es, para obtener un bienestar que no puede conseguir en la realidad. 
La cuestión de los paraísos artificiales, por ello, vendría a vincular esta novela con literatura posterior, pero no podemos olvidar que es tratada en un contexto puramente burlesco y desde una ideología ilustrada. A diferencia de lo que ocurre con De Quincey, aquí no se pretende de ningún modo despertar la empatía del lector hacia el protagonista, ni sugerir que el empleo de sustancias psicotrópicas sea algo aconsejable; con todo, el asunto de la hierba mora sirve de pretexto para deleitar al lector con nuevos y disparatados pasajes fantasiosos, lo cual está estrechamente relacionado con la intención principal del autor, esto es, entretener mediante la locura.

La hierba mora y el ansia de evasión que implica son cuestiones relacionadas, de hecho, con el tema principal de la novela, esto es, la locura a partir de un irracionalismo desbocado. Que el tío Gil intente evadirse a toda costa supone, precisamente, otra forma especialmente peligrosa de negar la realidad. La cantidad de experiencias desagradables que azotan a nuestro protagonista deberían bastar a cualquiera para hacerle escarmentar; sin embargo, toda posibilidad de aprendizaje queda impedida en El tío Gil Maтисо precisamente por esa necesidad de evasión tan presente en el protagonista, quien niega la posibilidad de aprender nada de la realidad al rechazarla en favor de otras realidades imaginarias que le resultan más agradables; en definitiva, la evasión aquí es otra forma de ir radicalmente contra la razón, la experiencia y lo empírico.

\section{CONCLUSIÓN}

Todo lo relativo a la «hierba mora» contribuye a consolidar, de igual manera, el carácter esencialmente lúdico de la obra, en contraposición al de la gran mayoría de imitaciones del Quijote en la España de aquellos años. A diferencia de lo habitual en estas otras, Vidal y Cabasés demuestra estar a la altura de las exigencias literarias de la época, presentes, sobre todo, en la Poética de Luzán, quien consideraba que «solo del feliz maridaje de la utilidad con el deleite nacen, como hijos legítimos, los maravillosos efectos que, en las costumbres y en los ánimos, produce la perfecta poesía» $(1977,185)$. Obras como el Quijote de la Cantabria, en cambio, podían tener mucho de crítica social, es decir, de «utilidad», pero no mostraban tanto cuidado en lograr una composición deleitosa; precisamente por eso mismo, entre otros motivos, fue también criticada esta otra obra por Jovellanos ${ }^{35}$. Así, y siguien-

35. «Pudo usted hacer la guerra a los vicios de los nobles, pintando un noble revestido de ellos, sacándolos a plaza en los varios incidentes de su acción y haciendo siempre que el éxito desgraciado o contrario a sus designios volviese en ridículo sus máximas, entretuviese a los lectores y sobre todo corrigiese con la burla a los que se le pareciesen. Este, sin duda, fue el camino que usted quiso seguir; pero ¿es este el carácter de su don Pelayo? No por cierto. Don Pelayo no tiene ni las virtudes ni los vicios de su clase. [...] Usted, sin embargo, pintó en Don Pelayo más bien el celo de un misionero o de un catequista que de un caballero virtuoso. Siempre predicando, siempre moralizando, parece que no es él el que habla, sino algún maestro de la religión o algún doctor de la Iglesia» (Jovellanos 1985, 598). El Quijote de la Cantabria, por ello, no logró estar a la altura de lo exigido por Luzán por no 
do el docere et delectare de Luzán, El tío Gil Mamuco ve en la obra de Cervantes no solo un molde desde el que criticar ciertos aspectos de la sociedad, sino también un referente que imitar en la composición de literatura con fines recreativos, esto es, utilizar los impredecibles desvaríos de un loco para entretener al público ${ }^{36}$.

Sin embargo, y tal como admitía en el prólogo a su novela, Vidal y Cabasés tampoco logra estar, del todo, a la altura de lo que pudiera dictaminar Luzán; como vimos, aseguraba haber podido crear algo mínimamente deleitoso, pero de dudosa utilidad. Tras un examen detenido de la obra, y habiendo contemplado la clara crítica social que en ella vemos, podríamos determinar que el novelista quizá esté pecando de falsa modestia o siendo demasiado crítico consigo mismo; no obstante, solo podemos hablar de un mensaje moral claro en El tío Gil Mamuco si la observamos en su conjunto, lo que resulta hasta cierto punto difícil dado lo relativo de su cohesión, debido, en parte, a su estructura acumulativa. Recordemos que Rodríguez Gutiérrez contemplaba, no sin parte de razón, considerar cada uno de los pasajes de la obra como cuentos o narraciones independientes $(2004,47)$. Hemos visto que, en su conjunto, contribuyen a componer un retrato más o menos concreto del protagonista, lo que no impide que, si juzgamos cada uno de ellos por separado, encontremos que no siempre parece clara la «utilidad» de algunos.

Que el tío Gil presuma de poseer un vergajo con propiedades mágicas supone una burla hacia quienes aún mantenían la creencia hacia lo sobrenatural. En ese caso, y volviendo de nuevo a la terminología de Ingarden, estaríamos ante un lugar de la obra completamente «determinado», que no da pie a lecturas opcionales. Pero todo esto, en cambio, es diferente en lo referente a los pasajes de la hierba mora, los cuales, en sí, no contienen, al menos explícitamente, ninguna clase de mensaje moral ni contribuyen a intensificar el que generalmente predomina en la obra. La indeterminación que vimos en estos sucesos nos impide advertir una crítica clara. Si asumimos que la hierba en cuestión es inútil y carece de propiedades, al igual que el resto de los sortilegios del tío Gil, podríamos interpretar tales capítulos como otra burla al esoterismo; sin embargo, esta no deja de ser sino una de las lecturas posibles que el lector podría llevar a cabo. No se puede descartar, no obstante, la otra posibilidad, que también queda sugerida; esto es, que la sustancia tenga propiedades psicotrópicas.

Como hemos visto, Vidal y Cabasés se sirve de lo «extraño puro», en términos de Todorov, para provocar una determinada sensación en el lector,

lograr, en ese caso, nada similar al deleite, sino que resultaba tan solo un texto moralizante que no proporcionaba demasiado agrado al lector que, como Jovellanos, se rigiera por el mismo criterio que el de la Poética.

36. La utilización del molde de Cervantes para componer un texto de esas características implica, nuevamente, cercanía para con las ideas de Luzán. Bien es cierto que este último, en su Poética, alude únicamente a textos en verso, y no contempla la novela en sí; no obstante, en cierta ocasión se refiere al Quijote como una obra «inmortal» $(1977,399)$, lo que remitiría a la obra cervantina como referente para las composiciones narrativas en prosa. 
que en este caso se vería desbordado por lo inquietante de lo que se plantea. Incluso si no hubiese dudas sobre los efectos alucinógenos de la hierba mora, los sucesos con esta se prestarían a interpretarse como una crítica a personalidades como Torres Villarroel. Por el contrario, al lector le está vetada toda información conclusiva al respecto, lo que cohíbe todo mensaje moral. Las críticas sociales que se infieran dependerán solo de la lectura que cada uno haga, no del texto en sí, lo que implicaría un distanciamiento, en esas partes de la novela, de los preceptos de Luzán. No podemos considerar «útiles», en la acepción usada en la Poética, unos pasajes en los que en modo alguno se esclarece cuál es esa «utilidad».

Pero, curiosamente, esta misma desviación con respecto a las reglas de su tiempo podría llevarnos a concederle otro tipo de mérito a la obra si la observásemos desde otra óptica. Una obra de estas características, al menos en esos pasajes, demandaría una mayor implicación por parte del lector, quien se vería «impulsado» a ser partícipe de la cocreación de la obra; y es que, para Ingarden, «el valor artístico de la obra de arte reside en aquellas cualidades que influyan en el observador estético y le muevan a la concreción de la obra constituyendo los componentes del fundamento óntico del valor estético que aún faltan» $(1989,50)$. De acuerdo con tal afirmación, el valor artístico de $E l$ tío Gil Mamuco sería superior al de obras que, por fidelidad a La poética de Luzán, evitarían la indeterminación a fin de clarificar el mensaje moral; no se hable ya de novelas como el Quijote de la Cantabria, en las que la excesiva explicitud ideológica podía lastrar toda posibilidad de «deleite».

Por este motivo, los pasajes con la hierba mora resultarían, quizá, los más interesantes del texto, si no desde la óptica de Luzán, sí a partir de cierta teoría literaria del siglo XX. A ello también se le añade que Vidal y Cabasés siga desviándose, en el resto de la obra, de las recomendaciones de La poética, y de un modo recurrente. Nos referimos a su insistencia por ahondar en la locura del tío Gil, cuyas excentricidades ocupan la mayoría de las páginas de la obra, con un detallismo que no siempre contribuye a incrementar la crítica hacia los curanderos, la gente de profesiones similares, las supersticiones en general o la población ociosa. La ridiculización de estos tendría lugar, exactamente en la misma medida, si el autor hubiese sido más breve en la mayor parte de las ocasiones. Que decida extenderse en estos casos no es algo que pueda explicarse buscando ninguna pretensión de «utilidad», sino que más bien responde a la intención de divertir al público mediante la contemplación de un estado mental enajenado. La posible experimentación con sustancias psicotrópicas, en este contexto, no dejaría de servir a ese mismo propósito.

A la luz, sobre todo, del mencionado texto de Vicente de los Ríos, no resulta difícil asumir que probablemente el autor se haya inspirado en una lectura muy concreta del Quijote para desarrollar una composición de estas características. Pero, actualmente, en una época posterior al trabajo de Torrente Ballester (1975) y otros similares, resultaría simplista reducir la grandeza de una obra como el Quijote a diversión a partir de la «locura» de su héroe; para el XVIII, en cambio, tal planteamiento no tenía por qué ser necesaria- 
mente más reduccionista que el de otros escritores. Muy significativo es el hecho, a este respecto, de que Vidal y Cabasés no haga en ningún momento alusión explícita al Quijote, una obra de la que desde luego es deudor. Lo habitual que en aquellos años era referenciar la novela de Cervantes en los títulos -Quijote de la Cantabria, Quijote escolástico, La Quijotita y su prima...- pone de manifiesto que, si el autor de El tío Gil Mamuco no llegó a comprender del todo las virtudes literarias del Quijote, al menos no alardeó de ello comparando a su personaje con el de Cervantes; comparación que, como hemos visto, solo podría sustentarse «falsificando» el significado de la novela cervantina, tal como ocurrió con tantos novelistas autores de diversas imitaciones llamadas, no con demasiado acierto, «Quijotes».

\section{BIBLIOGRAFÍA CITADA}

Álvarez Barrientos, Joaquín. 1991. La novela del siglo XVIII. Madrid: Júcar.

Álvarez Barrientos, Joaquín. 1996. «Novela». En Historia literaria de España en el siglo XVIII, coord. Francisco Aguilar Piñal, 235-284. Madrid: Trotta.

Álvarez de Miranda, Pedro. 1999. «La primitiva versión (1814) del Don Papis de Bobadilla de Rafael José de Crespo». En Ideas en sus paisajes. Homenaje al profesor Russell P. Sebold, coords. Guillermo Carnero, Ignacio Javier López y Enrique Rubio Cremades, 63-70. Alicante: Universidad.

Anzarena, Cristóbal de (Donato Arenzana). 1767. Vida y empressas literarias del ingeniosissimo caballero Don Quixote de la Manchuela, parte primera. Sevilla: Imprenta del Dr. Don Geronymo de Castilla.

Bardon, Maurice. 2010. El Quijote en Francia en los siglos XVII y XVIII. Alicante: Publicaciones de la Universidad de Alicante.

Blanco Martínez, Rogelio. 2004. «Estudio introductorio». En Eudoxia, hija de Belisario, Pedro Montengón, VII-LXXIX. Valencia: Universidad Politécnica.

Cervantes, Miguel de. 2010. Don Quijote de la Mancha, ed. Alberto Blecua. Barcelona: Espasa.

Chicharro Chamorro, Dámaso. 2005. «Don Quijote de la Manchuela. Un quijote andaluz en el siglo XVIII». Andalucía en la historia 10: 10-17.

Close, Anthony. 2007. Cervantes y la mentalidad cómica de su tiempo. Alcalá de Henares: Centro de Estudios Cervantinos.

Cotarelo y Mori, Emilio. 1900. Discursos leídos ante la Real Academia Española. Madrid: Imprenta Ducazcal.

Covarrubias, Sebastián de. 1611. Tesoro de la lengua castellana o española. Madrid: Luis Sánchez.

Cuevas Cervera, Francisco. 2015. El Cervantismo en el siglo XIX. Del Quijote de Ibarra (1780) al Quijote de Hartzenbusch (1863). Oviedo: Ediciones de la Universidad.

D. F. V. Y. C. P. (Francisco Vidal y Cabasés). 1789. El tío Gil Mamuco. Madrid: Oficina de Aznar.

De Quincey, Thomas. 2018. Confesiones de un inglés comedor de opio. Madrid: Alianza.

Escalante Varona, Alberto. 2019. «La droga literaria: una interpretación polisémica en los "sueños" de Diego de Torres Villarroel». En La enigmática piel de los drogados. Estupefacientes en la literatura hispánica, coords. Ana M. Díaz Pérez, Luis Fuente Pérez y Niklas Schmich, 39-60. Madrid: Philobiblion. 
Fabbri, Maurizio. 2012. «Introducción, edición y notas». En Vida, hechos y aventuras de Juan Mayorazgo, Félix Antonio Ponce de León. Rimini: Panozzo Editore.

Fajardo, Diógenes. 1985. «Erasmo y "Don Quijote de la Mancha"». Thesaurus XL, 3: 604-619.

Fernández, Luis Miguel. 2006. Tecnología, espectáculo, literatura. Dispositivos ópticos en las letras españolas en los siglos XVIII y XIX. Santiago de Compostela: Servizo de Publicacións e Intercambio Científico da Universidade de Santiago de Compostela.

Fernández de Lizardi, José Joaquín. 1967. La quijotita y su prima, ed. María del Carmen Ruiz Castañeda. México: Porrúa.

Figueras Pàmies. 1989. «La revolución en Cataluña. Ideas jurídicas de Ramón Martí de Eixalá». Anuario de filosofía del derecho VI: 221-236.

Forner, Juan Pablo. 2003. Exequias de la lengua castellana, ed. Marta Cristina Carbonell. Madrid: Cátedra.

García Gutiérrez, Rosa. 2007. «Quijote, mujer y cultura ilustrada. Alonso Quijano como antimodelo social. La Quijotita de Fernández de Lizardi». En Territorios de la Mancha. Versiones y subversiones cervantinas en la historia de la literatura hispanoamericana. Actas del VI Congreso internacional de la Asociación española de estudios literarios hispanoamericanos, coord. Matías Barchino, 323-335. Cuenca: Ediciones de la Universidad de Castilla-La Mancha.

Gautier, Théophile. 2020. El club de los hachisinos, seguido de La pipa de opio y El hachís. Navarra: José J. de Olañeta.

Genette, Gérard. 1998. Nuevo discurso del relato. Madrid: Cátedra.

Hernández Morillas, Josefa. 2014. Descripción documental de la vida y obra de Pedro María de Olive, un literato entre los siglos XVIII y XIX. Almería: Universidad.

Ingarden, Roman. 1989. «Corrección y reconstrucción». En Estética de la recepción, ed. Rainer Warning, 35-53. Madrid: Visor.

Iser, Wolfgang. 1989. «La estructura apelativa de los textos». En Estética de la recepción, ed. Rainer Warning, 133-148. Madrid: Visor.

Isla, José Francisco de. 1992. Historia del famoso predicador fray Gerundio de Campazas, alias Zotes, ed. José Jurado. Madrid: Gredos.

Jovellanos, Gaspar Melchor de. 1985. Obras completas. T. II, Correspondencia $1^{\circ}(1767-$ Junio de 1794), ed. José Miguel Caso González. Oviedo: Centro de Estudios del Siglo XVIII.

López Navia, Santiago. 2013. «Para una comprensión general de las recreaciones narrativas del Quijote en la literatura hispánica: actitudes y constantes». En Recreaciones quijotescas y cervantinas en la narrativa, ed. Santiago López Navia, 9-28. Pamplona: EUNSA.

Luna-Fabritius, Adriana. 2015. «Modernidad y drogas desde una perspectiva histórica». Revista mexicana de ciencias politicas y sociales 225: 21-44.

Luzán, Ignacio de. 1977. La poética. Reglas de la poesía en general y de sus principales especies, ed. Russell P. Sebold. Barcelona: Editorial Labor.

Martínez Mata, Emilio. 1998. «Pronósticos y predicciones de Diego de Torres Villarroel». En Revisión de Torres de Villarroel, coord. Manuel María Pérez López, 93-104. Salamanca: Ediciones de la Universidad de Salamanca.

Montengón, Pedro. 1998. Eusebio, ed. Fernando García Lara. Madrid, Cátedra.

Perdiguero Gil, Enrique. 1996. «Protomedicato y curanderismo». Dynamis. Acta Hispanica ad Medicinae Scientiarumque. Historiam Illustrandam 16: 91-108.

Ponce de León, Félix Antonio. 2012. Vida, hechos y aventuras de Juan Mayorazgo, ed. Maurizio Fabbri. Rimini: Panozzo Editore. 
Querol Coll, Enric. 2010. «La literatura d'època moderna». En Historia de les terres de l'Ebre, Art i cultura, eds. Jacobo Vidal y Jordi A. Carbonell, 253-276. Tarragona: Fundació ilercavònia Futur - Universitat Rovira i Virgili.

Ríos, Vicente de los. 1780. "Vida de Miguel de Cervantes Saavedra y Análisis del Quijote». En El ingenioso hidalgo don Quijote de la Mancha, Miguel de Cervantes, vol. 1, I-CLII. Madrid: Joaquín Ibarra.

Rivero Iglesias, Carmen. 2011. La recepción e interpretación del «Quijote» en la Alemania del siglo XVIII. Ciudad Real: Ayuntamiento de Argamasilla de Alba.

Roas, David. 2006. De la maravilla al horror. Los inicios de lo fantástico en la cultura española (1750-1860). Pontevedra: Mirabel Editorial.

Rodríguez Gutiérrez, Borja. 2004. Historia del cuento español (1764-1850). Madrid: Iberoamericana.

Samaniego, Félix María de. 2009. Fábulas, ed. Alfonso I. Sotelo. Madrid: Cátedra.

Sánchez Sánchez, Manuel Ambrosio. 2001. «Locura y sátira en las "novelas” quijotescas del siglo XVIII. Don Quijote el Escolástico». En La cara oculta de la razón: locura, creencia y utopía, coord. Cinta Canterla, 371-392. Cádiz: Servicio de Publicaciones de la Universidad de Cádiz.

Sebold, Russell. 1970. El rapto de la mente. Madrid: Prensa española.

Sieyès, Emmanuel. 2016. ¿Qué es el tercer estado? Ensayo sobre los privilegios, ed. Marta Lorente Sariñena y Lidia Vázquez Jiménez. Madrid: Alianza.

Todorov, Tzvetan. 2016. Introducción a la literatura fantástica. México D. F.: Coyoacán. Torrente Ballester, Gonzalo. 1975. El Quijote como juego. Madrid: Quadarrama.

Torres Villarroel, Diego de. 1998. Vida, ed. Dámaso Chicharro. Madrid: Cátedra.

Urzainqui Miqueleiz, Inmaculada. 1984. «La censura de "La conquista del Parnaso" y el fin de "El apologista universal" (1786-1788)». Archivium 34: 385-416.

Vidal y Cabasés, Francisco. 1778. Conversaciones instructivas en que se trata de fomentar la agricultura por medio del riego de las tierras. Madrid: Imprenta de D. Antonio de Sancha.

Vodička, Felix. 1989. «La estética de la recepción de las obras literarias». En Estética de la recepción, ed. Rainer Warning, 55-62. Madrid: Visor.

Recibido: 19 de agosto de 2020

Aceptado: 9 de mayo de 2021 